\title{
MANAGING THE RISK IN AGRICULTURE PRODUCTION: THE ROLE OF GOVERNMENT
}

\author{
Izabela Lipińska ${ }^{1}$
}

Received 20 February 2016; Accepted 30 June 2016

\begin{abstract}
The aim of the article was to define the essence and the role of state in managing the risk in agricultural production. Nowadays risk management is one of the core priorities of reformed CAP. Wherefore it was necessary to highlight the variety of tools and essay the reason why the farmers do not implement them. The main method applied in the work was a descriptive method and a dogmatic analysis of normative acts. Reference books and international analyses and reports were also used. The weather conditions, as well as climate change have fair impact on agricultural production, its quality and quantity, as well as farmers' income. They are infrequent but lead to severe damage to a whole region, like the droughts occurrence this year. Such events fall under the catastrophic risk layer, for which market solutions plays a less important role, mostly due to public involvement. Due to the current legislation, Member States have the authorization for granting subsidies for farmers who had loss. They set up provisions for damage recovery and compensation. It seems to be one of the main reasons why the farmers do not try to avoid the risk themselves applying some on-farm strategies.
\end{abstract}

Keywords: risk management, lost, damage, state compensation, common agricultural policy

Abstrakt: Celem artykułu było wskazanie istoty i roli państwa w zarządzaniu ryzykiem w produkcji rolnej. Obecnie problematyka zarządzania ryzykiem jest jednym z głównych celów Wspólnej Polityki Rolnej. Z tego względu koniecznym było zaprezentowanie różnych jego instrumentów, ze wskazaniem dlaczego rolnicy stosunkowo rzadko je stosują. Główną metodą wykorzystaną w pracy była dogmatyczna analizy aktów prawnych oraz metoda deskryptywna. Ponadto wykorzystano polską oraz zagraniczną literaturę przedmiotu. Warunki pogodowe, w tym w szczególności zmiany klimatu mają istotny wpływ na produkcję rolną, jej ilość i jakość, a tym samym oddziałują na dochodowość produkcji. Ich różnorodność, czy odmienne źródła prowadzą do strat. Mogą one obejmować swym zasięgiem duże obszary, jak to miało miejsce w przypadku suszy w 2015r. Takie incydenty są traktowane jako zdarzenia o randze katastroficznej. W ich przypadku rozwiązania z zakresu ryzyka, oparte na instrumentach rynkowych odgrywają mniejszą rolę, bowiem rolnicy oczekują pomocy ze strony państwa. Zgodnie z obowiązującym ustawodawstwem, każde państwo członkowskie UE może przewidywać wsparcie ad hoc dla poszkodowanych rolników. Odpowiednio rodzimy ustawodawca ustalił

\footnotetext{
1 Izabela Lipińska, PhD, Poznan University of Life Sciences, Faculty of Economics and Social Sciences, Management and Law Department, Wojska Polskiego 28, 60-637 Poznan, Poland; Email: lipinska@up.poznan.pl
} 
zasady likwidacji szkód, oraz udzielania pomocy. Jak ukazują przeprowadzone badania, to właśnie oczekiwanie na pomoc ad hoc i możliwość jej otrzymania w przyszłości powoduje, że rolnicy z niechęcią podejmują jakiekolwiek metody i instrumenty zarządzania ryzykiem w obrębie swojego gospodarstwa.

Słowa kluczowe: zarządzanie ryzykiem, strata, szkoda, pomoc państwa, Wspólna Polityka Rolna

\section{Introduction}

Risk management might be soon a key driver of agricultural policy. It is due to the climate change which is likely to increase the probability of extreme, unexpected and undesirable events. The paper focuses on the relations between the state and the farmers in the scope of managing the risk management in agricultural production. It relates to the legal tools offered by the state the application of which protects farmers from damage and loss. Besides these tools, in some situations the state offers different types of ad-hoc compensations (Martinez 2012).

The importance of the farmers' support and risk management is affected by the fact that agricultural activity and, in consequence, its profitability is largely precarious and unstable. It is exposed to particular risk and crises, which are beyond agricultural producers' control. The problem concerns both the effects of producers' decisions made at different stages of production and the negative consequences of natural disasters and other unpredictable incidents (Székely and Pálinkás, 2009). Agriculture is the sector that is particularly dependent upon the conditions of the natural environment and thus, it is exposed to a wide spectrum of risks, especially those which have climatic or natural background (Kimura, Anton, LeThi 2009).

The European Commission raised the issue that farmers should take over responsibility for risk management, which so far has been offset by the application of different economic and legal instruments. This implicates the need to create appropriate legislative conditions and encouragements for producers. The Communication from 2005 proposed three risk management tools, which are supposed to compensate the consequences of the CAP reform and support them against unexpected hazards (Communication, 2005). They cover insurance against natural disasters, mutual funds and income stabilization tools against its crises (Lipinska 2014; Schaffnit-Chatterjee 2010). They aimed to simultaneously replace ad-hoc emergency measures, offered by the state.

The issue of production risk has also been raised by the World Bank, which for a few years has been drawing up strategies which can be implemented by particular countries (Mahul, Stutley $2010)^{2}$. The strategies particularly emphasize preliminary risk assessment and the importance of identifying its sources as well as taking appropriate remedies. They may include any preventive measures designed to prevent risk, namely improving water management, selecting appropriate production means in the form of plant varieties more resistant to illnesses and pests or implementing early warning systems against natural disasters which may have a negative effect on production. Regulatory and market impediments are often invoked to justify public intervention in the provision of risk management tools. According to the World Bank, therefore, it is stated that should be able to identify limitations and take actions designed to help farmers to select suitable measures. The preventive measures, however, include mainly the instruments which must be preceded by collecting financial means. It refers to a so-called risk transfer and mitigating its negative effects. The former entails transferring risk on an assurance undertaking, namely insurance companies. The latter, in turn, assumes collecting savings or creating a "safety net" at the level of a region or a state in the form of mutual funds the significant role of which has been noticed, as previously stated, by the European legislator.

\footnotetext{
2 http://www.worldbank.org/en/topic/agriculture/brief/reduce-risk-vulnerability-and-gender-inequality-in-agriculture [Retrieved: 01.06.2016].
} 


\section{Aim, Material and Methods}

This article is an attempt to define the essence and the role of state in managing the risk in agricultural production. It is necessary to highlight the variety of tools and essay the reason why the farmers expect state support. What should be the role of the state? Shall it only manage the tools or support farmers in case of sudden loss caused by every unexpected situations and crises? These issues should be analysed individually at the level of each agricultural farm and its decisions. From the practical perspective it should be stated that larger agricultural farms are willing to take actions and apply production risk management instruments. Small farms, in turn, usually omit them and expect ad hoc aid. Simultaneously, as the study conducted by OECD found, both a type of risk and its consequences will affect farms of different sizes in a different way (Kimura, Anton, LeThi 2009).

The following analysis is going to be made in the context of organizational and production situation in Poland which occurred in 2015, particularly in connection with drought resulting in economic and social losses. The meteorologists expect persisting high temperatures and lack of moist in the next few years. They may lead to the occurrence of systemic risk, which will affect a number of farms in Poland. If ad hoc aid from the state budget is continued, it will lead to increasing expenses.

Therefore, the research hypothesis should be that state ad hoc aid results in fewer farmers, especially those whose production scale is lower, who consciously opt for the instruments intended to mitigate negative consequences of production risk.

Having done the literature research it needs to be emphasized that the issue in question has been raised by specialists in many fields from the theoretical, practical as well as holistic perspective (Anton 2015). Special attention should be given particularly to papers by S. Kimura, J. Anton and C. LeThi "Farm Level Analysis of Risk and Risk Management Strategies and Policies: Cross Country Analysis, OECD Food, Agriculture and Fisheries Working Papers" from 2010, "Managing Risk in Agriculture: A Holistic Approach" by OECD Organisation for Economic Cooperation and Development from 2009 and "Managing Risk in Agriculture - Policy Assessment and Design" also worked out by OECD in 2011. Among the recent papers I would like to point to the most significant ones, namely Risk Management in Agriculture: What Role for Policy in the New Common Agricultural Policy? J. Anton and the report made this year under the guidance of T. Garcia-Azcárate: "Research for Agri Committee - State of Play of Risk Management Tools Implemented by Member States during the Period 2014-2020: National and European Frameworks".

The issue in question seems to be very important for a few reasons. What mostly speaks in favor of discussing it is the fact that agricultural production depends on numerous external factors and insurance, which is a basic instrument of risk management, usually does not cover a full spectrum of events causing damage to production. Any negative events, especially catastrophic, don't allow execute plans and it can be a cause of abandonment of farms by farmers. This can upset the situation on food market. What is more, numerous managementrelated issues have no legal definition, which makes it far more difficult to draft effective legal acts. At the same time, due to multiple management methods it is necessary to set the ceiling at the level of agricultural farms and the state.

The main method applied in the work was a descriptive method and a dogmatic analysis of Polish and EUs' normative acts. The report analyses, first of all, the basic European legal act which specifies and gives the Member States guidelines as to the shape of the legal and agricultural policy they use in respect of managing production risk. Then, it discusses the core of domestic regulations in the context of the purpose of the paper. The starting point for all analyses and final conclusions consisted of papers worked out by OECD (Organisation for Economic Cooperation and Development), European report as well as Polish and foreign books on the subject. 


\section{Legal bases for production risk management in the European Union}

The establishment and support given to risk management schemes was listed as one of the specific objectives in the reformed CAP. The preamble to Regulation (EU) No 1305/2013 of the European Parliament and of the Council of 17 December 2013 on support for rural development by the European Agricultural Fund for Rural Development (EAFRD) and repealing Council Regulation (EC) No 1698/2005³ mentions the need to provide aid to farmers to solve the problems related to the most common risk types. It triggers the government to establish national schemes to encourage farmers to protect their income against the loss and damage.

The role of European regulation relies on specifying the financial support for risk management tools. The tools themselves have to be regulated at the state level. Thus the state has a main role in designing the regulation for the proper risk management. EU allows to subsidize them from its budget. According Article 36 of Reg. 1305/2013 there are three measurements: a) financial contributions to premiums for crop, animal and plant insurance against economic losses to farmers caused by adverse climatic events, animal or plant diseases, pest infestation, or an environmental incident; b) financial contributions to mutual funds to pay financial compensations to farmers, for economic losses caused by adverse climatic events or by the outbreak of an animal or plant disease or pest infestation or an environmental incident and c) an income stabilization tool, in the form of financial contributions to mutual funds, providing compensation to farmers for a severe drop in their income. The state has to ensure that overcompensation as a result of the combination of this measure with other national or Union support instruments or private insurance schemes is avoided (Lipińska 2014).

As insurance is concerned, support may only be granted for insurance contracts which cover for loss caused by an adverse climatic event, an animal or plant disease, a pest infestation, an environmental incident or a measure adopted in accordance with Directive 2000/29/EC ${ }^{4}$ to eradicate or contain a plant disease, or pest which destroys more than $30 \%$ of the average annual production of the farmer in the preceding three-year period or a three-year average based on the preceding five-year period, excluding the highest and lowest entry. The used calculation method shall permit the determination of the actual loss of an individual farmer in a given year.

In this case, the state has to formally recognize the occurrence of an adverse climatic event or the outbreak of an animal or plant disease or pest infestation or an environmental incident. In the name of the state the recognition is done by the competent authority. Besides, the state may establish in advance some criteria on which basis such formal recognition shall be deemed to be granted.

The state has to set the rules of establishment of mutual funds and their management, especially the rules concerning the payment of compensations and farmers' eligibility in case of crisis as well as the management and monitoring of compliance with these rules (JanowiczLomott 2013). Apart from that, in the case of the farmer's negligence they also provide for penalties under the conditions of the funds.

According to Article 38, Regulation 1305/2013, before mutual funds are eligible for support, they must be accredited by the competent authority and in compliance with the national law. Thus the state should define the specific procedure to accomplish its duty. Apart from that, funds should have an explicit policy concerning contributions and payment of compensations and they should have clear rules concerning the division of responsibility for debts (Lipińska 2015).

As far as the financial contribution is concerned, according to the applicable legal regulations, it may still concern the administrative costs of establishment of funds spread for the maximum period of three years, but with degressiveness applied. Apart from that, the contribution may also include the amounts paid by the mutual fund as the financial compensation for farmers. Moreover, the financial contribution may also concern the interest on commercial loans incurred by the mutual fund in order to pay financial compensation to farmers if there is a crisis.

\footnotetext{
${ }^{3}$ Official Journal L 347, 20.12.2013, pp. 487.

${ }^{4}$ Official Journal L 169, 10.07.2000. pp. 1-112.
} 
The legislature introduces the obligation for the competent authority of the state to formally declare the occurrence of an environmental incident. However, the support is only provided to cover the loss caused by the occurrence of one of the following incidents, i.e. disastrous weather conditions, animal or plant diseases, pest infestations, environmental incidents, which damaged more than $30 \%$ of the farmer's average annual production in the previous three years or the average value for three years calculated on the basis of the previous five years, excluding the highest and lowest values. Coefficients may be used to calculate the annual production of a specific producer. The applied method of calculation must enable determination of the real loss suffered by an individual farmer in a specific year.

According to Appendix II to Regulation No 1305/2013, the maximum level of subsidies still cannot exceed $65 \%$ of eligible costs. The state may limit those costs by the introduction of ceilings related with the fund or respective individual ceilings.

As income stabilization tool is considered, the role of the state consists of defining the rules for the constitution and management of the mutual funds, which is the only entity from the organizational point of view, authorized to run the toll. In particular the state is also responsible for the granting of compensation payments to farmers in the event of crisis and for the administration and monitoring of compliance with these rules. Furthermore it shall ensure that the fund arrangements provide for penalties in case of negligence on the part of the farmer. The government has to accredit the mutual fund as the entity.

The instruments in question have been provided for at the level of the European Union. Except for them, the state may provide for other forms of support for farmers who will decide to start actions aimed at enhancing their economic safety if a risk factor arises. These forms of support may include both public and private help.

\section{Legal conditions of production risk management in Poland}

\section{Crop and animal insurances}

As far as the Polish market is concerned, the most important tool against the risk is crop and livestock insurance. Under the Act of 7 July 2005 on subsidies to crop and livestock insurance 5 a farmer is obliged by law to make an insurance agreement with a selected insurance company (Klimkowski 2013). These are mostly companies with whom the Minister of Agriculture and Rural Development made an agreement on subsidies. They constitute a form of encouragement for farmers to take out policies and the state contributes towards the premiums from the budget. The farmers are entitled to get subsidies under the insurance agreement in relation to two types of force majeure events. The first one is connected with a plant production relating to cereals, maize, rape, turnip rape, hop, tobacco, field vegetables, fruit trees and bushes, strawberries, potatoes, sugar beets or leguminous plants from sowing to harvesting against the risk of losses caused by hurricane, flood, heavy rain, hail, thunder, ground fall, avalanche, drought, negative effects of winter time or spring frost. The second one, however, is connected with an animal production (i.e. cattle, horses, goats, poultry or pigs) and the scope of events range from hurricane, flood, heavy rain, hail, thunder, ground fall, avalanche to obligatory slaughter. Under the Act, an agricultural producer may insure their crops and livestock against all types of risk listed in the Act or against only some of them, selected by the producer.

The main aim of insuring crops and livestock is to compensate the losses resulting from a negative event which leads to a decrease in a farmer's income. Pursuant to Article 6 (1) of the Act in question, the insurance covers the losses which were suffered on agricultural farms as a result of events covered by the insurance policy.

As for insuring the crops, an insurance company compensates the losses caused, first of all, by hurricane, flood, heavy rain, hail, thunder, ground fall, avalanche, negative effects of winter time and spring frost if the loss in the main crop amounts to at least $10 \%$, and, second of all, caused by draught if the loss in the main crop amounts to at least $25 \%$.

\footnotetext{
${ }^{5}$ Polish Journal of Laws No. 150, item 1249, with latest amendments.
} 
It is worth mentioning that pursuant to Article 5 of the Act, the subsidies amount to $65 \%$ of the premium for crop insurance if insurance tariff rates specified by the insurance companies do not exceed:

a) as for the cultivation of cereals, maize, spring oilseed rape, turnip rape, potatoes or sugar beets $-3.5 \%$ of the insured sum of crops; if the types of risks are divided, the insured sum refers to all types of risk,

b) as for winter oilseed rape, field vegetables, hop, tobacco, fruit trees and bushes, strawberries or leguminous plants $-5 \%$ of the insured sum; if the types of risks are divided, the insured sum refers to all types of risk;

As for livestock, however, the subsidies amount to $65 \%$ of a premium for livestock insurance if insurance tariff rates specified by the insurance companies do not exceed $0.5 \%$ of the insured sum.

Crop and livestock insurance defines the link between the insurance and direct payments. If a farmer was granted direct payments, he is obliged to make a crop insurance agreement against the losses caused by flood, draught, hail, negative effects of winter time and spring frost. The insurance obligation is fulfilled if, starting from 1 July of the year following the date where the farmer was granted direct payments, within 12 months, at least $50 \%$ of the planted area is covered by an insurance policy. An agricultural producer who did not comply with the regulations is obliged to pay the equivalent of EUR 2 per 1 ha calculated on the basis of an average exchange rate announced by the National Bank of Poland. As long as the agricultural producers who do not abide by the regulations on crop and livestock insurance are not subject to severe penalties and sanctions, these regulations will not be effective.

\section{Mutual Funds}

At present there is no legal basis for the establishment and functioning of mutual funds in Poland. The initiation of funds requires the introduction of certain internal regulations with a procedural character. The establishment of mutual insurance companies requires that one should meet the premises specified in the general Insurance Activity Act of 22 May $2003^{6}$. The premises particularly concern the capital and personal requirements, complex organizational and administrative requirements, etc. The mutual funds should be adjusted to the needs of a specific product or group of products. Accordingly, narrow groups of producers will participate in such funds and they will not be competitive to large specialized insurance companies. Therefore, it is necessary to formulate such legal framework for the establishment of mutual funds in Poland that would enable the use of the national and EU measures of tax deductions and credit facilitations.

\section{Income stabilization fund}

As far as the instrument of income stabilization is concerned, a bill connected with creation of Fund of Mutual Help in stabilization of Agricultural Income was presented a year ago (State 2014). It predicts the rules of creation, tasks, finance, organization and functioning of mentioned fund, which aim is to create legal possibilities which guarantee agricultural producers stabilization of income from agricultural activity in case of lowering or in case of lack of getting payment for sold agricultural products from subject, which is insolvent. The Fund is to be created by payment from subject buying agricultural products, to process or resell them, for subjects dealing with business activity in scope of fishing in inland waters or sea and subjects connected with activity of breeding. Works on a new Act are still being held.

\section{Contract farming}

The production contract is another well-recognized risk management tool. It is the contract of delivery of pre-contracted agricultural produce under which an agricultural producer undertakes to produce and provide to a pre-contracting party a specified amount of agricultural produce of

\footnotetext{
${ }^{6}$ Polish Journal of Laws from 2003, No. 124, item 1151, with latest amendments.
} 
a determined kind and the pre-contracting party undertakes to collect that produce within time limit agreed on and performs specified additional performance if the contract or specific provisions provide for a duty to render such performance (Article 613 of Civil Code) ${ }^{7}$. It allows spread risk of run production. As a so-called rule of divided risk says, pursuant to Article 622 of Civil Code, the consequences of failure to perform the agreement due to the reasons which do not depend on a farmer, are spread on both parties.

\section{Lease contract}

Another solution is provided by the lease contract which also ensures the spread of risk among lessee and lessor (Article 700 of Civil Code). If, due to circumstances for which the lessee is not liable and which do not concern it, ordinary revenues from the leased object are considerably decreased, the lessee may demand a reduction in the rent due for the given business period. The Civil Code does not specify the minimum decrease in profitability of the lease object (Lichorowicz, 2011). According to commonly accepted standards, it usually refers to situations where the revenues fall by at least one third. Such a solution is expected to provide the farmer with more economic stability. The relevant regulations, however, are not precise, which makes it difficult to apply them. A solution similar to the one included in the Code has been provided for by the Regulation of the Minister of Agriculture and Rural Development of 19 November 2009 on detailed conditions of the deferment, spreading into instalments or remission of liabilities of the Agricultural Property Agency and the procedures for these cases ${ }^{8}$. In such a case, the rent liabilities may be reduced or even remitted in full, pursuant to $\S 2$ (3) (6) if a farmer, among others, suffered a loss as a result of drought, flood, ground fall, hurricane or infestation of pests. The Regulation, however, defines neither a natural disaster nor the type and extent of a loss. A prerequisite conditions for the remission of the payment of rent is that the Agency of Agricultural Property determines whether a farmer will have enough means to run an agricultural activity in a much limited scope, which may result in the employees being dismissed (Lichorowicz, 2011).

\section{Tax exemption and credit facilitates}

Another form of state activity connected with the production risk are tax reliefs or the remission of agricultural tax. Pursuant to Article 13c of the Act of 15 November 1984 on Agricultural Tax ${ }^{9}$, in the event of natural disaster which caused substantial losses in agricultural products or livestock, the amount of the relief or the extent of the remission depends on the scale of losses caused by natural disaster on an agricultural farm. This legislative solution stays in force until the end of this year. As of 1 January 2016 the above-mentioned solutions are to be applied if the state declares a state of emergency due to natural disaster mentioned in the Act of 18 April 2002 on a State of Natural Disaster ${ }^{10}$.

Additionally, those agricultural producers who suffered drought-related losses may apply for loans in the banks which cooperate with the Agency for Restructuring and Modernisation of Agriculture (ARMA). They are so-called working disaster loans intended for the purchase of necessary means of agricultural production such as, e.g. fodder, fertilizers, plant protection chemicals, seed grain. The loan amount which an agricultural farm can get amounts to maximum PLN 5 million. The borrower is not required to provide his own contribution but he is expected to document at least $50 \%$ of expenditure incurred by means of the loan. The loan period can be arranged with a bank but the Agency can apply subsidies for no longer than 4 years from the date of loss occurrence. According to the conditions of the aid offered by ARMA, a farmer repays only part of interest due and the remaining part is paid by the Agency. The interest rate that a farmer has to pay depends on two factors. Firstly, whether the farmer has a relevant insurance and secondly, on the bank that the farmer will want to take out a loan from. Considering those two elements, the interest rate paid by the farmer amounts to $1.74 \%$ -

\footnotetext{
${ }^{7}$ Act of 23 April 1964 - Civil Code, Polish Journal of Laws No. 16, item 93, with latest amendments.

8 Polish Journal of Laws No. 210, item 1619, with latest amendments.

9 Polish Journal of Laws No. 52, item 268, with latest amendments.

10 Polish Journal of Laws No. 0, item 333 and 915.
} 
$2.09 \%$, if on the date where damage occurred at least $50 \%$ of surface area of crops, except for grasslands and pastures, or at least $50 \%$ of the number of farm animals or special branch of agricultural production was insured against at least one natural disasters and $2.61 \%-3.1350 \%$ if the farmer did not have such insurance. If the losses amount to $30 \%$ or less of a yearly production in a farm, the subsidy from the Agency will be perceived as de minimis aid in agriculture ${ }^{11}$.

The last year drought resulted in some farmers falling behind schedule in repaying the preferential investment loans taken out in the previous years. The state offered some solutions in that respect. The solutions provided the affected farmers with the following options: extending the repayment of the instalments of capital and interest, provided that the due date under the loan agreement has not expired yet, extending the term of the loan or, in justified cases, extending the term of the loan by additional three years beyond the maximum term ${ }^{12}$.

\section{Ad hoc support}

Currently, one of the biggest problems having a downright dramatic impact on the situation of agricultural producers is drought and huge drought-related losses.

The drought, which particularly affected some of European countries was caused by a combination of prolonged rain shortages and exceptionally high temperatures (European Drought, 2015). In Poland so far, the loss was evaluated in more than 200 thousands farms in the area of 1097532 hectare amounted of 1 billion PLN. It is assumed that the drought may cover about $12.5 \%$ of arable land and $50 \%$ of surface of the bush cultivation and fruit trees.

Typically, farmers can determine whether to participate in a government program on an annual basis. Participation in one program may require participation in other applicable programs (cross compliance). However, farmers can analyze potential effects of participation or nonparticipation based on their individual circumstances and specifics of the program. Participation may be advantageous in some years and not in others. Obligatory insurance of crops by law exists only theoretically. In practice, it is farmers' business decision. In case of climatic risk mostly chosen is hailstorm insurance. The reason is the insurance fee. Regulations applied in Poland cause that the drought insurance is especially difficult. The risk is too high that the policy fee exceeds maximum rates, determined by legal norms and then farmers can't count on extra charge from the Budget. At the same time, the compensation is very low. According to available data, only 86 farmers were insured against drought (Sawicki 2015). For comparison, over one million 300 thousand applied for direct payments. The other problem is to determine responsibility of the company. According to regulations, it should join when there is at least $30 \%$ of loss in crop. The problem is that there is no data which allow to determine the overdraft of threshold and real value of losses.

Therefore, it is needed to introduce changes in regulations, which don't allow to sell policy against drought on wide range. As a result of the situation there is a need to offer public help for harmed farmers. The most important elements are low-interest loan on preferential terms (for instance to resume agricultural production, for regeneration of fixe capital assets), fee exemption, or let pay bank loans in stages.

The Agency for Restructuring and Modernization of Agriculture (ARMA) provides financial help for each hectare of farming, where drought occurred, declared by agricultural producer in application, in amount maximally 400 PLN for 1 hectare, and in case of bearing fruit trees and

\footnotetext{
11 See: Commission Regulation (EU) No 1408/2013 of 18 December 2013 on the application of Articles 107 and 108 of the Treaty on the Functioning of the European Union to de minimis aid in the agriculture sector, OJ L 352, 24.12.2013, p. 9-17 and Commission Regulation (EU) No 702/2014 of 25 June 2014 declaring certain categories of aid in the agricultural and forestry sectors and in rural areas compatible with the internal market in application of Articles 107 and 108 of the Treaty on the Functioning of the European Union, OJ L 193, 1.7.2014, p. 1-75.

12 See:http://www.arimr.gov.pl/pomoc-krajowa/udogodnienia-w-splacie-zaciagnietych-kredytow-preferencyjnych-zdoplatami-z-arimr.html [Retrieved: 2.06.2016].
} 
fruity bushes - in amount maximally 800 PLN for 1 hectare ${ }^{13}$. This help is of temporary character and unfortunately it doesn't lead to take action to run risk in farm in the next season.

\section{The role of the state in production risk management in the European and Polish legislation}

The risk management issue is a vital element of the state policy, including the EU agricultural policy. It is justified by the vulnerability of farmers to agricultural production risks. The EU legislator enabled the Member States to shape the risk management policy. However, only the outline of how the particular measure should be used was provided and the final decision as to their extent and implementation was left to be laid down by the domestic regulations. The reason behind it was, among other things, that throughout the European Union the types of risks, their consequences as well as the agricultural production itself and agricultural markets are highly diversified. The state is supposed to form legal framework which enables agricultural producers to take preventive measures since it is agricultural producers who are best positioned to know the dimension, characteristics and correlations of the risks that affect their farms. Single farmer is also the best positioned to evaluate the availability of different strategies to deal with this risk. It is the farmer's responsibility as manager of his own farming business to take the appropriate decisions to manage the risk associated with his economic activity (Kimura, Anton, LeThi 2009).

At the same time, two aspects need to be given special consideration. Firstly, the scope of the state intervention relating to the issues of risk in agricultural production has long been causing both political disputes and scientific discussion. These disputes mainly cover the question of financing negative consequences of production risk and the fact that the risk is not possible to be eliminated irrespective of the actions taken by the governments. The EU legislator aims rather at minimizing the public aid which, by the rule, impairs competitiveness on the market, by means of supporting private entities which provide protection in a difficult and not independent agricultural sector. For example, the requirement of insuring crops and farm animals introduced in Poland relieves the burden on the national public sector. At the same time, the fact that farmers do not comply with the obligation to take out insurance does not affect, for instance, their eligibility to apply for direct payments from the general EU budget. It should, however, affect the eligibility to apply for aid from the domestic budget if natural disasters occur.

Secondly, the reference books, especially OECD reports (Kimura, Anton, LeThi 2009; OECD 2011), distinguish three risk layers based on the likelihood of occurrence and the extent of potential losses (Hardaker 2004, Tangermann 2011). The reports mention normal, marketable and catastrophic risks. The normal risk should be perceived as a regular business surrounding and managed by a farmer. The state should refrain from taking any mitigating actions. The marketable risk, in turn, should be eradicated by means of market instruments, such as insurances. In this case the state should implement relevant legal regulations enabling both making an insurance agreement covering specific risks and reinsurance. As for the catastrophic risk, it needs to be indicated that there are no instruments that would eliminate it. The ad hoc aid on the part of the state can be the only support for the affected farmers.

It is the state - legislator that is expected to differentiate between and define those risks as it falls into the scope of shaping risk management policy. As Kimura, Anton and LeThi (2010) emphasize in their research, the government policy negatively influences the extent to which risk management instruments are used. They even prove that some solutions which existed before the reform of the Common Agricultural Policy in respect of private risk management were limited by public solutions. The state, therefore, should strive to keep private actions and some market solutions, for example, by means of supporting private insurances.

\footnotetext{
${ }^{13}$ Resolution No. 147/2015 of the Council of Ministers of 31 August 2015 on establishing aid program for farmers and agricultural producers who suffered losses in their agricultural farms or special branches of agricultural production caused by drought in 2015. RM-111-148-15. http://www.minrol.gov.pl/Informacje-branzowe/Niekorzystne-zjawiskaatmosferyczne-pomoc.
} 
Additionally, the state risk policy needs to be of a holistic and not particular character. At the same time, the state should separate the issues of social support from intervening in the agricultural activity which in many countries is perceived as a form of a business activity.

As emphasized in "Research for Agri Committee - state of play of risk management tools implemented by member states during the period 2014 - 2020: national and European frameworks", governments have a responsibility to bridge the gaps left out by the private sector and develop an enabling for the development of privately offered risk management tools (Garcia-Azcárate T. et al. 2016). It is necessary, however, to ensure that the different legislations and different member states do not bring market distortions or tilt the playing field in favour of some farmers. The authors states that any insurable risk should never be compensated with ad-hoc payments.

\section{Conclusion}

First of all, the proposed by European Commission legal tools of risk management do not cover all the measures that might apply in agricultural production. The legislator proposes only the most significant which need the proper regulation. As a result, everything is left to the decisions of the member states. There is still the lack of juridical solutions in Poland. Without some - quite often political movements, less social ad hoc support and more strict responsibilities concerning insurance the farmers will not take the responsibility of the risk management within their farms. Risk management strategies start with decisions on the farm and the household. The farmer sets of outputs to be produced, decides on the allocation of land, the use of other inputs and techniques, such as diversification of activities on and off-farm.

For risk reduction and mitigation, there are government actions that are ex ante (like disaster prevention) but the scale of ex post ones trigger farmer's inaction. They expect to be given aid which has been provided for in the form of acts (like the tax system or the possibility to change the terms and conditions of a contract of delivery of pre-contracted agricultural produce or a lease contract) as well as in the form of state actions which protect family farms, as specified in Article 23 of the Polish Constitution. Both preventive and aid measures, therefore, need to be finely balanced. What needs to be emphasized is that ad hoc aid should depend on taking some specified, preferably under statutory regulations, preventive measures within the farm. It would be necessary to use the above-mentioned basic instruments such as, for example, agricultural insurances. The state aid should relate to the situations which, first of all, could not be covered by the existing means and, secondly, when the scale significantly exceeded the expected negative consequences. Additionally, as the OECD report of 2009 indicated, a major thrust is that farmers should be empowered to take responsibility for risk management, and policy actions should enable correlations among farming risks to be exploited. A variety of instruments should be available to the farmer so that he can choose the instrument that best fits his needs. The system should facilitate the production and sharing of information.

As far as the assumed research hypothesis is concerned, different government policies and programs contribute to reducing risk directly or indirectly through the market mechanism they support. But if there are risks that are somehow covered by government programs, the small farmer's incentives to use other strategies are then reduced. Government policy should, therefore, not deal with individual risks separately, but adopt a broader view of the overall pattern and implications of risk affecting farmers.

There should be a holistic approach to risk management in government policies. It has to be based on assessing all types of risks and their relationships to each other. Thus the role of the state shall not only be based only on financial support, but also on helping them to evaluate and manage the risk on their own farms. Therefore more information and training should be provided. Besides the government role might be significant in reducing informational asymmetries especially in insurance programs (Mahul and Stutly, 2010). They face moral hazard and adverse selection, which are very difficult to measure by private insurance companies. The state can maintain agricultural and weather databases as public goods that makes easier to design the insurance contracts. 
It is very positive that government has been increasingly involved in the support of agricultural insurance programs, but it also should be more focused on commercial ones. A limited number of insurance companies offering subsidized crop insurance contributes to the lack of competition on the insurance market. The crop and animal insurance should not be the only tool applied by the farmers. They have to take responsibility for losses and damage by applying various instruments directly on a farm. Therefore, state aid should be perceived as complementary to the actions taken by the farmers themselves. The state should identify the regulatory impediments and create new solutions to help farmers implement them as part of their risk management activities.

The role of the state in supporting the income of agricultural producers is significant but it should not be used until the instruments implemented by a farmer are effective. The state, by its legal nature, should support its citizens and their activities. But government policies should not provide support to deal with normal risk. Managing normal risk should be the preserve of farmers themselves.

As far as ad-hoc compensation is concerned, however, some changes should be made. Farmers expect the aid and that is why they do not take many actions to prevent losses. The problem arises, as it happened last summer, when the systemic risk appears and affects a large number of farmers. Providing post-disaster aid limits both farmers' initiative and their responsibility for the actions they take regarding an agricultural production activity. Additionally, ad-hoc aid results in fewer farmers making crop insurance agreements and that is why these instruments should be, to some extent, limited. Proposed by EU mutual funds or instruments of income stabilization may only supplementing solutions and possibility of using them is determined by concluding a contract of crop insurance. Therefore, there is a need to create a certain stimulus to enter at least the insurance contracts.

\section{Acknowledgement}

The article was prepared under research grant OPUS n 2013/09/B/HS5/00683: Legal instruments of risk management in agriculture production, funded by the National Science Centre.

References

[1] Anton, J. (2015). Risk Management in Agriculture: What Role for Policy in the New Common Agricultural Policy? (pp. 86-110). In McMahon, J. A., Cardwell, M. N., eds., Research Handbook on EU Agriculture Law. Cheltenham: Edward Elgar. DOI: 10.4337/9781781954621.00013.

[2] Communication from the Commission to the Council on risk and crisis management in agriculture, $\operatorname{COM}(2005) 74,09.03 .2005$, [Retrieved: 2014-09-05].

[3] European Drought Observatory (EDO) Drought News August 2015, http://edo.jrc.ec.europa.eu/documents/news/EDODroughtNews201508.pdf. [Retrieved: 2015-08-29].

[4] García-Azcárate, T. et al. (2016). Research for Agri Committee - State of Play of Risk Management Tools Implemented by Member States During the Period 2014-2020: National and European Frameworks. Brussel: European Parliament's Committee on Agriculture and Rural Development.

[5] Hardaker, J. B., Huirne, R. B. M., Anderson, J. R. \& Lien, G., eds. (2004). Coping with Risk in Agriculture. Wallingford: CABI Publishing.

[6] Janowicz-Lomott, M. (2013). Mutual fund jako forma zarządzania ryzykiem w rolnictwie (pp. 63-77). Prace i Materiały Wydziału Zarządzania Uniwersytetu Gdańskiego No. 2/5.

[7] Kimura, S., Anton, J. \& Lethi, C. (2009). Managing Risk in Agriculture: A Holistic Approach. Paris: OECD. 
[8] Kimura, S., Anton, J. \& Lethi, C. (2010). Farm Level Analysis of Risk and Risk Management Strategies and Policies: Cross Country Analysis. OECD Food, Agriculture and Fisheries Working paper, No. 26. Paris: OECD.

[9] Klimkowski, C. (2013). Ubezpieczenia rolne a zmiany Wspólnej Polityki Rolnej. Journal of Agribusiness and Rural Development 29(3), 41-49.

[10] Lichorowicz, A. (2011). Dzierżawa (pp. 200-204). In Panowicz-Lipska, J., ed., Prawo zobowiązań - część szczegółowa. System Prawa Prywatnego.T. Vol. 8. Warszawa: C.H.Beck.

[11] Lipińska, I. (2014). Wspólna Polityka Rolna wobec problemów zarządzania ryzykiem. Rural Law Review 14(1), 93-108.

[12] Lipińska, I. (2015). Mutual funds as a legal instrument of risk management in agriculture (pp. 181-191). Agricoltura Istituzioni Mercati 1-2, 181-191. DOI: 10.3280/AIM2013-001011.

[13] Mahul, O. \& Stutley, Ch. (2010). Government Support to Agricultural Insurance: Challenges and Options for Developing Countries. Washington: The World Bank.

[14] Martinez, J. (2012). Risikomanagement im Agrarsektor Der Völker und europarechtliche Rahmen (pp. 75-93). In Frentrup, M., Theuvsen, L. \& Emmann, C. H., eds., Risikomanagement in Agrarhandel und Lebensmittelindustrie. Clenze: Agrimedia Verlag.

[15] OECD (2011a). Synthesis Report on Risk Management in Agriculture. Document TAD/CA/APM/ WP(2011)4FINAL. Paris: OECD.

[16] Pawłowska-Tyszko, J. (2009). Aktualne problemy zarządzania ryzykiem w rolnictwie. Komunikaty Raporty Ekspertyzy. Warszawa: IERiGŻ-PIB.

[17] Sawicki, M. (2015). Data from the interview with the Polish Minister of Agriculture and Rural Development, by Gawęda, M. www.biznes.pl [Retrieved: 18.08.2015].

[18] Schaffnit-Chatterjee, C. (2010). Risk management in agriculture. Towards market solutions in the EU. Frankfurt am Main: Deutsche Bank.

[19] State project on Fund of Mutual Help in stabilization of Agricultural Income. Print No. 3076. 2014. http://www.sejm.gov.pl/sejm7.nsf/druk.xsp?nr=3076 [Retrieved: 2015-08-30].

[20] Székely, C. \& Pálinkás, P. (2009). Agricultural Risk Management in the European Union and in the USA. Studies in Agricultural Economics 109, 55-72.

[21] Tangermann, S. (2011). Risk Management in Agriculture and the Future of the EU's Common Agricultural Policy, Issue Paper, No. 33. 